Article

\title{
Do External or Internal Technology Spillovers Have a Stronger Influence on Innovation Efficiency in China?
}

\author{
Xionghe Qin and Debin Du* \\ Institute for Innovation and Strategic Studies, East China Normal University, Shanghai 200062, China; \\ 52163902008@stu.ecnu.edu.cn \\ * Correspondence: dbdu@re.ecnu.edu.cn
}

Received: 10 August 2017; Accepted: 1 September 2017; Published: 5 September 2017

\begin{abstract}
In this study, we bridge an important gap in the literature by comparing the extent to which external technology spillovers, as indicated by foreign direct investment (FDI), and internal technology spillovers, as indicated by university-institute-industry cooperation (UIC), influence innovation efficiency in China. We divide the innovation process into two sequential stages, namely the knowledge creation and technology commercialization stages, and employ a network data envelopment analysis approach to measure innovation efficiency at each stage. The spatial analysis of the distribution of knowledge creation efficiency and technology commercialization efficiency reveals the heterogeneity of innovation efficiency at the provincial level. Then, a panel data regression is used to analyze the effect of FDI and UIC on innovation efficiency at each stage, using data from 2009 to 2015 for 30 provinces in China. By comparing FDI with UIC, we find that FDI has a higher coefficient and stronger significance level at the knowledge creation stage, while only industry-institute linkages exhibit a stronger association with innovation efficiency at the technology commercialization stage.
\end{abstract}

Keywords: foreign direct investment; university-institute-industry cooperation; innovation efficiency; external and internal technology spillover; network DEA; China

\section{Introduction}

In the knowledge era, innovation is recognized as a driving force of sustainable economic development and innovation-driven growth is no longer the prerogative of high-income countries alone [1,2]. As a developing country, China has raised expenditure on research and development (R\&D) markedly while also designing policies to enhance the country's innovation performance. However, while China's output of publications and patents is impressive, there are very few genuine innovations [3]. Against the backdrop of the "Silicon Valley Miracle" and "Cambridge Phenomenon", the output and transformation of genuine innovations play a pivotal role in economic growth [4]. As China's economic expansion has fallen to the so-called "new normal" pace [5], the pattern of heavy $R \& D$ investment in the long term is unsustainable, placing greater focus on increasing the contribution of innovation outputs to economic growth by improving innovation efficiency rather than the blind expansion of R\&D expenditure. Hence, improving innovation efficiency must be the focus of national efforts to allocate innovative resources reasonably and facilitate indigenous innovation in order to sustain economic growth.

Increasing regional innovation performance mainly depends on two technology spillover effects. On the one hand, to accelerate scientific and technological innovation, host regions could absorb international technology spillovers as indicated by foreign direct investment (FDI) through imitation, competition, and personnel flows. This mechanism is defined as "external technology spillovers" herein. On the other hand, local R\&D activities fostered by university-institute-industry cooperation (UIC) can encourage indigenous innovation by exploiting innovators' resources and 
sharing complementarities among universities, institutes, and industry [6-8]. This mechanism is defined as "internal technology spillovers" herein. However, the empirical question of whether external or internal technology spillovers are most adept at improving innovation efficiency remains largely unexplored. The present study aims to bridge this gap in the body of knowledge on this topic.

Since the start of its reform and opening up era, China has attracted substantial foreign capital because of the country's low labor costs and preferential tax policies, which, to some extent, have promoted technological progress and innovation. However, in recent years, FDI flows have slowed because of the weakened demographic dividend and narrowing technical gap between domestic and foreign enterprises. These factors have gradually reduced the role of FDI in improving innovation efficiency. Meanwhile, the level of human resources has gradually increased because of China's continuously rising educational level. Indigenous innovation fostered by the UIC has thus begun to play an increasingly prominent role in improving innovation efficiency. This reason makes it necessary to compare the influences of FDI and UIC on innovation efficiency and identify which mechanism has the stronger influence.

Most previous research has tended to regard the innovation process as a "black box", ignoring the internal structure and operating mechanisms of the innovation system. However, innovation is a complex process involving the consumption of a range of inputs, development of a scientific process, and production of a series of outputs that demands cooperation among all the actors of the innovation system [9-13]. As a result, cooperation efforts and innovative inputs and outputs differ from stage to stage. Based on the foregoing, to represent innovation efficiency in the whole process accurately, we refer to the definition of the innovation value chain $[14,15]$ and divide the innovation process into the knowledge creation and technology commercialization stages. This consecutive process may include both an upstream sub-process (knowledge creation) and a downstream sub-process (technology commercialization) [16]. This fact suggests that the outputs generated in an upstream sub-process may become intermediate inputs in a downstream sub-process. To determine the appropriate production process that best represents innovation production, we employ the network data envelopment analysis (DEA) approach to measure innovation efficiency. From this perspective, a panel dataset is then built to investigate and compare the influence of FDI with that of UIC on innovation efficiency in each stage, covering 30 provinces in China from 2009 to 2015. The presented analysis offers specific policy actions to improve the use of internal and external technology spillovers.

The remainder of this paper is organized as follows. Section 2 reviews the literature and develops the hypotheses of the study. Section 3 presents the methodology and data collection approaches. Section 4 presents the empirical results. Finally, Section 5 concludes.

\section{Literature Review and Hypotheses Development}

\subsection{External and Internal Technology Spillovers in Regional Innovation}

This study brings together two strands of the literature. One focuses on the influence of external technology spillovers, as indicated by FDI, on innovation efficiency, while another discusses fostering local innovation performance through UIC to achieve technological progress.

Within the former stream of the literature, a number of studies have analyzed the influence of FDI on innovation performance through three major effects: the promotion effect, inhibition effect, and threshold effect. In terms of the promotion effect on knowledge creation, Vahter [17] shows that FDI can promote the flow of knowledge from foreign countries to domestic enterprises. According to $\mathrm{Fu}$ [18], FDI has significantly positive effects on managerial knowledge spillovers to local firms, as demonstrated by the author's empirical evidence of their effects through the diffusion of management practices. With regard to the promotion effect on technology commercialization, $\mathrm{Li}$ et al. [19] investigate the degree to which the presence of FDI influences technology commercialization by emerging market firms and find that the diversity of industries with a foreign presence contributes to technology commercialization by Chinese firms. Girma et al. [20] show 
that FDI promotes new product sales by China's domestic firms provided that they have sufficiently high R\&D intensity and good access to financial resources.

As for the inhibition effect, Hou et al. [21] show that FDI as a source of external knowledge has a significant negative impact on green innovation growth but with different constraints on R\&D levels among industries. Elmawazini and Nwankwo [22] claim that FDI has had little impact on the industrial development and global competitiveness of countries in sub-Saharan Africa and has rather widened the gap between them and developed countries. However, Pan [23] finds a threshold effect on external technology spillovers in regional enterprises. FDI in western China has not crossed the threshold (i.e., it has not positively influenced innovation performance), while the spillover effect of FDI in the eastern region is decreasing and that in the central region is gradually increasing. Finally, by using the theory of competitive dynamics, Meyer and Sinani [24] suggest that the spillover effect of FDI is closely related to human capital, income, and the institutional framework.

Within the strand of the literature related to the impact of UIC on innovation, the rapid development of knowledge and technology has prevented any enterprise from forging a technological advantage in all sectors [25]. Maietta [9] examines whether university-firm R\&D collaboration has positive effects on process innovation, finding that university policies that aim to commercialize R\&D outputs negatively affect regional innovation. Indeed, among the linkages cultivated by universities, institutes, and industry, only contractual relationships have a direct and significant effect on innovation, whereas relational activities simply serve to promote and support contractual activities [26]. However, more studies confirm that UIC has a positive impact on innovative outputs. For example, in terms of industry-university linkages, George et al. [27] show that companies with university linkages have lower R\&D expenses and higher levels of innovative output. Likewise, university-firm R\&D cooperation affects process innovation in low-tech industries [9]. UIC-subsidized universities and the presence of a formal UIC management mechanism drive improvements in academic innovation performance [28]. As for the industry-institute relationship, the technology novelty of industrial innovation is positively related to the collaboration between industry and institutes; in other words, the greater the collaboration, the higher is the technology novelty of the innovation [29]. Referring to institute-university cooperation, Gemünden et al. [30] claim that technology-oriented external relationships such as linkages to universities and research institutes are a critical factor for the success of a firm's technological innovation, which in turn is the main determinant of commercial innovation success.

Summing up, relatively few studies have quantified the impact of FDI and UIC on innovation efficiency. Moreover, innovation has been characterized as a process from input to output [31] that combines knowledge creation and knowledge commercialization. As innovation activities and UIC could occur in the stages of knowledge creation and technology commercialization, it is necessary to employ different indicators to measure innovation efficiency in each stage. In addition, no study comparatively analyzes the impact of FDI and that of UIC on innovation efficiency from the perspective of multistage innovation. These are the considerations upon which the study relies to offer novel evidence in this field.

\subsection{Hypotheses Development}

\subsubsection{FDI and Innovation Efficiency}

A rising number of studies are exploring the FDI-innovation relation, mostly confirming the positive influence of FDI on innovation activities in the host country [32]. Multinational companies (MNCs), as the main providers of FDI, enter host countries and compete with domestic firms and other MNCs. To seek competitive advantage, the R\&D institutions of MNCs are likely to increase their R\&D investment and cooperate with the host country's R\&D institutions to localize their R\&D activities. In doing so, the development and application of high-technology products bring the host country a larger quantity of innovative outputs in the technology commercialization stage. Therefore, FDI has a 
positive effect on innovative output in the technology commercialization stage through direct external technology spillover effect.

In addition, through its indirect external technology spillover effect, FDI could also positively influence innovative outputs in the knowledge creation stage. First, as technological innovation is passed through the innovation value chain, MNCs can spill technology into the knowledge creation stage through forward correlation spillovers in the innovation value chain [33]. More specifically, to better carry out R\&D activities in the technology commercialization stage, MNCs would employ professional talents and obtain knowledge from the upstream actors in the value chain such as institutes and universities where the spillover occurs. To achieve the high requirements of MNCs in the technology commercialization stage, institutes and universities in the knowledge creation stage must then improve the quality of knowledge and innovative outputs and train superior technicians and R\&D personnel for MNCs. In other words, FDI can positively influence innovative outputs in the knowledge creation through forward correlation spillovers in the innovation value chain. Hence, we propose the first set of hypotheses:

Hypothesis 1a (H1a). FDI positively affects innovation efficiency in the knowledge creation stage.

Hypothesis $\mathbf{1 b}(\mathbf{H 1} \mathbf{b})$. FDI positively affects innovation efficiency in the technology commercialization stage.

\subsubsection{UIC and Innovation Efficiency}

Few studies have explored the influence of UIC on innovation efficiency in the context of multistage innovation. While UIC can enhance innovation performance [27,34], the nature of knowledge flows among universities, institutes, and industry and the consequent innovation-related benefits may differ according to the interaction channel and innovation stage [9]. Furthermore, innovation actors either complement or substitute each other, in the latter case mostly because researchers in universities or institutes may be time constrained and less able to engage in technology and product transformation projects.

Industry-university cooperation and industry-institute cooperation enable enterprises to access the latest scientific inventions as well as the cutting-edge science and technology provided by universities and institutes [35]. Unlike enterprises that typically acquire external knowledge only through the publication of journal papers and purchase of patents, such cooperation can help the $R \& D$ personnel in the enterprise cooperate with the R\&D experts in universities and institutes [36]. This degree of cooperation in diverse academic fields greatly increases the opportunity for innovation subjects to acquire tacit knowledge [37]. Further, some studies have pointed out that the motivation of enterprises to cooperate with universities and institutes is not only for the commercialization of innovative outputs, but also for the opportunity to access highly trained and talented students as well as emerging technologies [38,39]. In addition, as universities and institutes are characterized by a strong R\&D capacity and abundant labor resources, respectively, cooperation between universities and institutes could complement their individual advantages when carrying out joint R\&D projects. That is, university-institute cooperation, industry-university cooperation, and industry-institute cooperation may help improve innovation efficiency. Therefore, we hypothesize the following:

Hypothesis 2a (H2a). UIC positively affects innovation efficiency in the knowledge creation stage.

Hypothesis $\mathbf{2 b} \mathbf{( H 2 b )}$. UIC positively affects innovation efficiency in the technology commercialization stage.

\subsubsection{FDI and UIC}

Finally, both external and internal technology spillovers can improve innovation performance in developing countries. Some studies confirm that the core technology of foreign countries does 
not flow into the host country through FDI, because MNCs are likely to shift production to Chinese firms rather than transfer technology in order to maintain their technological superiority [40]. Thus, achieving genuine innovations should rely on indigenous innovation in the host country, namely internal technology spillovers through UIC. Hence, we put forward the following set of hypotheses:

Hypothesis 3a (H3a). UIC shows a stronger influence on innovation efficiency than FDI in the knowledge creation stage.

Hypothesis $\mathbf{3 b} \mathbf{b} \mathbf{H} 3 \mathbf{b})$. UIC shows a stronger influence on innovation efficiency than FDI in the technology commercialization stage.

\section{Methods}

\subsection{Conceptual Framework for the Innovation Process}

As indicated above, this study seeks to develop a two-step analytical procedure for measuring stages of innovation performance, for which it is necessary to construct a process-oriented conceptual framework of regional innovation processes. Innovation is a complex process, and it should be evaluated as such, rather than as a single input-output activity [41]. In this study, following the literature, we divide the innovation process into two stages: (1) the generation and development of innovation; and (2) the transformation and dissemination of innovation [14]. The popular definition of innovation proposed by Forrester has generally led researchers to explore the innovation process from a production perspective [42]. In this framework, innovation is considered to be an input-output production process that contains multiple stages and multiple factors in an innovative value chain. In this context, a multistage model divides the process into two sequential sub-processes (Figure 1).

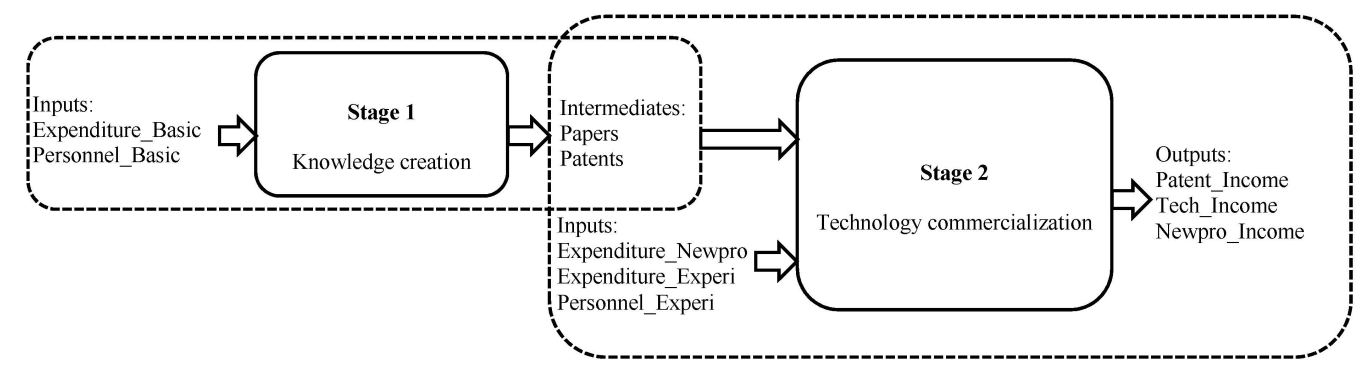

Figure 1. Two-stage chain process of innovation.

The upstream sub-process is the knowledge creation stage, which determines whether innovation actors can efficiently use funding and human resources to develop new research and academic outcomes. The downstream sub-process is the technology commercialization stage, which examines whether innovation actors can take advantage of its patents and technologies to develop new social and economic values. The input and output variables differ from stage to stage. The main purpose of the knowledge creation stage is to understand a phenomenon, grasp natural law, and obtain basic principles of knowledge to provide ways in which to solve problems. The significance of the multiple stages is to distinguish between direct outputs and intermediate outputs from innovation inputs and to consider possible intervening processes, which, to some extent, open the "black box" in regional innovation processes.

Network DEA was adopted, which considers a network of "divisions" or "sub-processes" to assess appropriately the divisional efficiencies and the overall efficiency of innovation (Figure 1). We specify the inputs in the knowledge creation stage as $R \& D$ expenditures on basic and applied research and R\&D personnel engaged in basic and applied research (Expenditure_Basic and Personnel_Basic) and the outputs as the numbers of publications and patents. Inputs in the technology commercialization stage 
not only include intermediate inputs (i.e., publications and patents), which result from the knowledge creation stage but also serve as the foundation for technology commercialization as manpower and material inputs (i.e., R\&D expenditures on experimental development and new products development and R\&D personnel engaged in experimental development (Expenditure_Experi, Expenditure_Newpro and Personnel_Experi)). The outputs in this stage are mainly in the form of economic benefits that include revenue from patent licensing and technology assignment and sales revenue of new product (Patent_Income, Tech_Income and Newpro_Income). We then calculate efficiency scores for each node and the whole process.

\subsection{Network DEA}

This study sets up an innovative chain process framework of cross-regions for regional innovation activities in 30 provinces in China. Each province is regarded as a decision making unit (DMU) that employs R\&D expenditures and manpower as inputs to produce quantity and quality output indicators. Traditionally, DEA proposed by Charnes et al. [43] has treated each DMU as a "black box" by considering only the inputs consumed and final outputs produced, ignoring the links among sub-DMUs and, thus, making it hard to identify ways for the DMUs to improve their performances. In most real situations, DMUs can perform several functions and be separated into different components in series. In this case, some components play important roles in generating outputs by investing intermediate outputs obtained from their previous components. To open the "black box" of the innovation process, we propose a DEA network model that deals with the chain relationships among sub-DMUs and solves the problem of the standard DEA model in that it does not consider intermediate products [44,45].

Previous studies have proposed the network DEA model to utilize the radial measure of efficiency in the traditional DEA model [46,47]. Tone and Tsutsui [48] further introduce a non-radial network slacks-based measure (SBM) approach to evaluate efficiency. The advantage of the network SBM is that efficiency decreases strictly monotonically with the change in the degree of input and output slacks and it has stronger resolving power compared with traditional network DEA [49]. In this case, we employ the following objective function and define overall innovation efficiencies corresponding to the network SBM by

$$
\min \rho_{0}^{*}=\frac{\sum_{k=1}^{K} w^{k}\left[1-\frac{1}{m_{k}}\left(\sum_{i=1}^{m_{k}} \frac{s_{i o}^{k-}}{x_{i o}^{k}}\right)\right]}{\sum_{k=1}^{K} w^{k}\left[1+\frac{1}{r_{k}}\left(\sum_{i=1}^{r_{k}} \frac{s_{0}^{k+}}{y_{r o}^{k}}\right)\right]} \text { s.t. } \begin{cases}\sum_{k=1}^{K} w^{k}=1, w^{k} \geq 0(\forall k) \\ x_{0}^{k}=X^{k} \lambda^{k}+s_{0}^{k-} \quad(k=1, K, K) \\ y_{0}^{k}=Y^{k} \lambda^{k}-s_{0}^{k+} \quad(k=1, \mathrm{~K}, K) \\ e \lambda^{k}=1 \quad(k=1, K, K) \\ S_{0}^{k+}, S_{0}^{k-}, \lambda^{k} \geq 0,(\forall k) \\ z_{0}^{(k, h)}=Z^{(k, h)} \lambda^{h} \quad(\forall(k, h)) \\ z_{0}^{(k, h)}=Z^{(k, h)} \lambda^{k} & (\forall(k, h))\end{cases}
$$

where $X$ and $Y$ are, respectively, the input vector and the output vector; $m$ and $r$ are the number of inputs and outputs; $S$ are the slack variables of input and output; and $w^{k}$ is the weight of sector $k$, whereby $e \lambda^{k}=1$ indicates that the leading surface of production technology is constructed under the assumption of variable returns to scale. $z^{(k, h)}$ represents the linking inputs to DMU at division $h$ from division $k$, and the linking outputs to DMU at division $k$ from division $h$.

In this study, we define the divisional efficiency score of division $k$ by

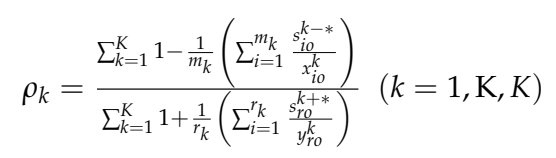

where $s^{*}$ are optimal input- and output-slacks for Equation (1). If $\rho_{0}^{*}=1$, then $\mathrm{DMU}_{0}$ is referred to as $R \& D$ "efficient", which indicates that universities' R\&D efficiency is the highest. If $\rho_{k}=1$, the division $k$ in $\mathrm{DMU}_{0}$ is $\mathrm{R} \& \mathrm{D}$ "efficient". 


\subsection{Variables in the Panel Data Mode}

\subsubsection{Dependent Variables}

Innovation is a multistage process that involves the transformation of the inputs of innovative elements into the outputs of innovative products. Innovative outputs are heterogeneous in value, with most worth little [50]. Therefore, rather than simply focusing on counts of innovative outputs, recent work has examined innovation efficiency to characterize genuine innovation. According to the concept of the innovation value chain [15], we employ a network SBM model to calculate innovation efficiency (dependent variables) in two stages, namely knowledge creation efficiency (CRE_EFCY) and technology commercialization efficiency (COM_EFCY).

\subsubsection{Independent Variables}

One important channel that contributes to innovation efficiency is FDI. First, one can expect external knowledge and technology spillovers to influence the innovative outputs and R\&D activities of incumbents because of greater competition, which can increase the incentive to innovate and raise efforts to source external knowledge in order to overcome rivals [51]. In addition, technology transfer can drive external technology spillovers through FDI and thereby affect innovation efficiency. One example of technology transfer is the imitation of production processes used by foreign-owned firms, but new to incumbent firms [17].

UIC, as an indicator of measuring internal technology spillovers, is another channel that influences innovation efficiency. However, cooperation between different innovators exerts different influences on innovative outputs. For example, industry-university and industry-institute cooperation differ in their degree of interconnectedness as well as innovation goals [52]. Therefore, to investigate the role of internal technology spillovers in innovation efficiency, UIC can be divided into institute-university cooperation (C_INS-UNI), industry-university cooperation (C_IND-UNI), and industry-institute cooperation (C_IND-INS). Their cooperation can be expressed by mutually commissioned R\&D projects. For example, industry-institute cooperation consists of R\&D projects commissioned by industry to institutes and by institutes to industry. Therefore, we employ expenditure for R\&D projects mutually commissioned between universities and institutes, institutes and industry, and universities and industry to measure the magnitude of C_INS-UNI, C_IND-UNI and C_IND-INS, respectively. Institute-university cooperation dominates the knowledge creation stage. In the technology commercialization stage, industry-university and industry-institute cooperation a more common. Therefore, the type of UIC differs by innovation stage.

\subsubsection{Control Variables}

As is typical in province-level analyses, the model controls for a set of factors likely to relate to innovation efficiency. Expenditure on R\&D (R\&D investment) is an important factor determining one's ability to absorb technology, which may lead technology spillovers to significantly affect innovation efficiency [53]. This variable thus captures the notion of absorptive capacity [54] in that innovative objects that produce their own innovative outputs are better able to use the externally available resources.

In addition, the quality of a university might affect knowledge creation efficiency. Based on global university rankings in Shanghai ranking list, we employ a dummy variable to measure the quality of a university (Q_UNIVERSITY) according to a four-point scale $(0=$ no university in the top 500 list; 1 = only one university in the top 500 list; 2 = two universities in the top 500 list; and $3=$ more than two universities in the top 500 list). We also control for average firm size (AVE_FIRMSIZE), as this may affect the efficiency of technology commercialization. AVE_FIRMSIZE is expressed as total average assets. The other two factors are selected as proxies of the external environment. The first variable considered is the Internet penetration rate (i.e., the proportion of the population using the Internet relative to the total population). This variable is used as a proxy of information 
technology infrastructure (INFRASTRUCTURE) [55]. Government support (GOVERN_SUP), measured by the proportion of government expenditure on science and technology relative to total government expenditure, which partly reflects the government's promotion of innovation activities by enhancing the innovative environment and providing funding, is the other proxy used.

Our analysis also uses two control variables: per-capita GDP (per-capita GDP) and the quality of R\&D personnel (Q_PERSONNEL). First, technology transfer is highly positively correlated with per-capita GDP [56] and thus per-capita GDP is used as a proxy of market demand (i.e., a short-term increase in innovative products raises demand for new technologies). This will have promotional effects on the quantity of R\&D personnel, equipment, and accumulation of knowledge stock and therefore it facilitates a country's innovation infrastructure and environment [57]. Second, the quality of $R \& D$ personnel (Q_PERSONNEL) reflects the innovative level of $R \& D$ labor.

\subsection{Data}

This study is based on a balanced panel dataset of 30 provinces in China observed over 2009 to 2015. It regards a region as the research object and focuses on the interaction among industry, institutes, and universities within that region. The above variables related to nominal prices are measured in constant 2009 prices after deflation by a GDP deflator. The GDP deflator $P$ was obtained as the ratio of GDP in current prices to an index of GDP in constant 2009 prices. Data were obtained from the China Statistical Yearbook on Science [58] and the China Statistical Yearbook [59]. Tibet is excluded from this study because of a lack of relevant data. Data compiled by the National Bureau of Statistics are used to generate official innovation statistics for China, which have been used extensively to analyze the fields of management studies [60] and economic geography [61].

\section{Results}

\subsection{Evaluation of Innovation Efficiency}

The estimated innovation efficiency scores are briefly presented before their relations with FDI and UIC are analyzed. We employ a network SBM model to calculate the CRE_EFCY, COM_EFCY, and overall innovation efficiency (INN_EFCY) in 30 provinces in China from 2009 to 2015 (Figure 2).

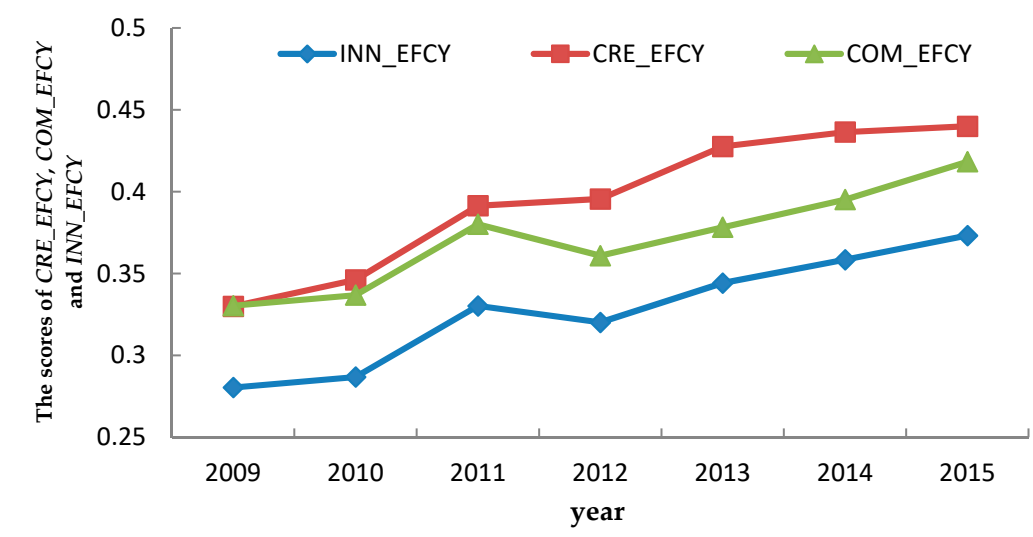

Figure 2. Changing trends of CRE_EFCY, COM_EFCY, and overall INN_EFCY in China during 2009-2015. The vertical coordinates denote the evaluation scores of CRE_EFCY,COM_EFCY and INN_EFCY, and the evaluation scores range from 0 to 1 .

Generally, average INN_EFCY over the period is 0.328 , which is still a relatively low level. However, INN_EFCY shows a gradual upward trend, rising from 0.280 in 2009 to 0.373 in 2015, a 9.3\% increase. This finding reveals that there has been a significant improvement in regional INN_EFCY in recent years. Furthermore, the average scores of $C R E \_E F C Y$ and COM_EFCY, which are based on the 
network relationship, are 0.395 and 0.371 , respectively. As for the decomposition of overall INN_EFCY, $C R E \_E F C Y$ has a higher average score and more efficient processes than COM_EFCY.

Based on the average score of INN_EFCY, the INN_EFCYS of the 30 provinces are divided into four grades (high, medium, low, and very low) using the classification method of natural breaks (Figure 3) [62]. As shown in Figure 3, provinces with low or very low INN_EFCY are mainly located in northwestern China, while provinces with medium or high INN_EFCY are mainly located in coastal provinces and central areas. One explanation for this could be that coastal provinces have easier access to internationalization strategies that enable them to absorb advanced knowledge and technologies through scientific and technological exchanges and cooperation with foreigners [63]. In addition, innovative actors in coastal provinces are more open than those in inland areas and face fiercer international competition, which could help them gain advanced technology and managerial experience through technological spillovers or the "learning effect" [64], resulting in INN_EFCY that is better than that of the central regions [65]. Further, the scores of CRE_EFCY are higher than those of COM_EFCY, mainly in southeastern provinces (Figure 3). By contrast, provinces with higher values of COM_EFCY are located in northwestern China. The spatial distribution of CRE_EFCY and COM_EFCY reflects the heterogeneity of innovation efficiency at the provincial level. This finding clearly suggests that the econometric model should be based on provincial panel data. The empirical analysis is presented in the next subsection.

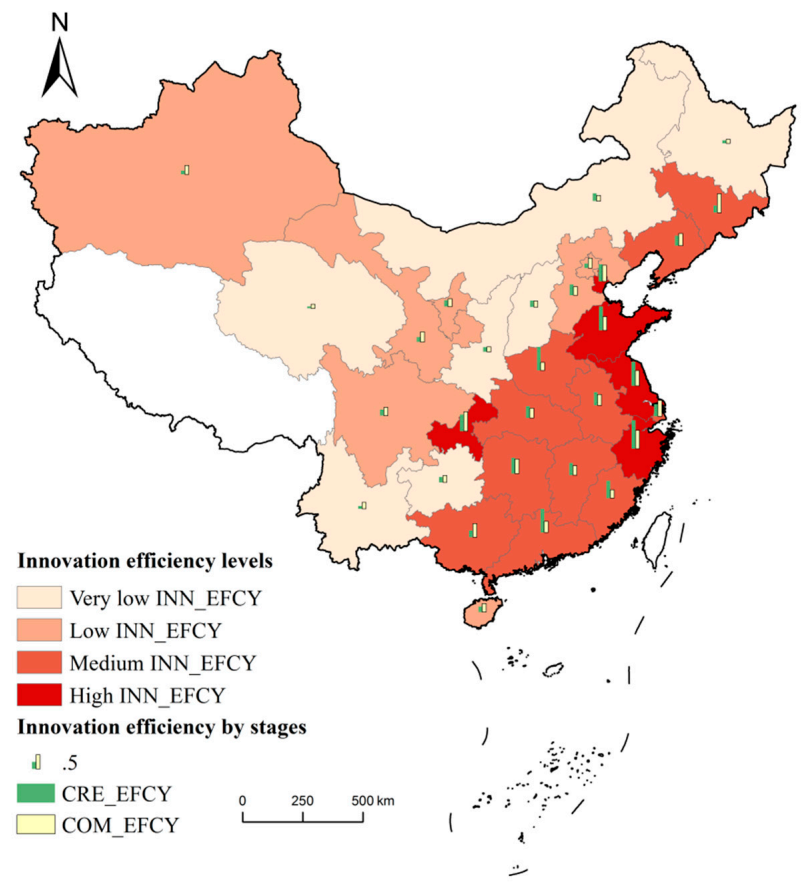

Figure 3. Spatial patterns of INN_EFCY in China.

\subsection{Econometric Analysis}

Table 1 presents the descriptive statistics and correlation matrix, confirming that innovation efficiency is significantly associated with UIC. The means of CRE_EFCY and COM_EFCY are 0.395 and 0.371 and their standard deviations are relatively large. Similarly, the provinces have means of 7837.8 for C_INS-UNI and 56884.4 for C_IND-INS, but with considerably larger standard deviations (15374.2 and 70784.7, respectively), which reflects the heterogeneity of innovation activities and UIC at the province level. We calculated the variance inflation factor (VIF) scores for each term to ensure that our models are not confounded by multicollinearity. The VIF for each variable is below 10 (the highest VIF value is 5.66), suggesting low multicollinearity among the parameters [66]. 
Table 1. Descriptive statistics and correlation matrix.

\begin{tabular}{|c|c|c|c|c|c|c|c|c|c|c|c|c|c|c|c|}
\hline & \multirow{2}{*}{$\mathbf{N}$} & \multirow{2}{*}{ Mean } & \multirow{2}{*}{ SD } & \multicolumn{12}{|c|}{ Correlation } \\
\hline & & & & 1 & 2 & 3 & 4 & 5 & 6 & 7 & 8 & 9 & 10 & 11 & 12 \\
\hline 1. CRE_EFCY & 210 & 0.395 & 0.272 & 1 & & & & & & & & & & & \\
\hline 2. $C O M=E F C Y$ & 210 & 0.371 & 0.175 & $0.539 *$ & 1 & & & & & & & & & & \\
\hline 3. FDI & 210 & $785,464.8$ & $807,681.2$ & $0.671 *$ & $0.380 *$ & 1 & & & & & & & & & \\
\hline 4. C_INS-UNI & 210 & 7837.8 & $15,337.5$ & 0.025 & 0.086 & $0.256^{*}$ & 1 & & & & & & & & \\
\hline 5. C_IND-INS & 210 & $56,884.4$ & $70,615.9$ & $0.486 *$ & $0.256 *$ & $0.571^{*}$ & $0.539 *$ & 1 & & & & & & & \\
\hline 6. C-IND-UNI & 210 & $30,586.9$ & $33,438.0$ & $0.494 *$ & $0.206 *$ & $0.559 *$ & $0.512 *$ & $0.749 *$ & 1 & & & & & & \\
\hline 7. RED investment & 210 & 4.227 & 5.982 & $0.133 *$ & 0.234 * & $0.396^{*}$ & 0.837 * & $0.524 *$ & $0.486 *$ & 1 & & & & & \\
\hline 8. Q_PERSONNEL & 210 & 1.713 & 0.434 & $-0.155 *$ & -0.058 & -0.058 & 0.025 & -0.104 & -0.088 & 0.080 & 1 & & & & \\
\hline 9. per-capita GDP & 210 & 4.267 & 2.119 & -0.043 & -0.042 & 0.066 & $0.119 *$ & 0.058 & $0.120 *$ & $0.241 *$ & $0.175^{*}$ & 1 & & & \\
\hline 10. GOVERN_SUP & 210 & 0.245 & 0.137 & $-0.690 *$ & -0.273 * & -0.364 * & $0.370 *$ & $-0.136 *$ & -0.149 * & $0.228 *$ & 0.131 & 0.014 & 1 & & \\
\hline 11. INFRATRÜCTURE & 210 & 42.609 & 13.628 & $0.328 *$ & $0.306 *$ & $0.448 *$ & $0.493 *$ & $0.445 *$ & $0.283 *$ & $0.638 *$ & -0.010 & -0.073 & -0.064 & 1 & \\
\hline 12. Q_UNIVERSITY & 210 & 1.605 & 1.226 & -0.068 & 0.020 & 0.099 & 0.075 & 0.012 & 0.074 & $0.216^{*}$ & $0.392 *$ & 0.639 * & 0.033 & -0.009 & 1 \\
\hline 13. AVE_FIRMSIZE & 210 & $32,640.8$ & $20,849.0$ & -0.062 & 0.022 & -0.095 & -0.035 & -0.058 & -0.123 * & -0.053 & $0.404 *$ & $0.138 *$ & 0.084 & -0.014 & -0.060 \\
\hline
\end{tabular}

SD—standard deviation, ${ }^{*} p<0.1$. 
The hypotheses proposed in Section 2 are evaluated by using panel regression analyses. Following the majority of previous studies $[67,68]$, the variables are expressed either in logarithm form or in ratios. This strategy aims to make the estimation less sensitive to outliers and allow for the easy interpretation of the estimated coefficients [69]. Note that for all six models below we also carried out Hausman tests [70] to test the null hypothesis $\mathrm{H}_{0}$ of random effects against the alternative $\mathrm{H}_{\mathrm{a}}$ of fixed effects, which is used to test for systematic differences between the RE and FE models. If the null hypothesis of no significant differences is rejected, then there is unobserved heterogeneity and the FE estimator is preferred. Otherwise, the RE estimator leads to unbiased results.

First, we examine the association between FDI and innovation efficiency. In Model 1, the Hausman test with a $p$-value less than 0.05 shows that there is significant unobserved heterogeneity, so that the FE specification is preferred. As shown in Table 2, FDI has a significant influence on CRE_EFCY and COM_EFCY, confirming that external technology spillovers to some extent positively affect innovation efficiency. These findings support H1a and H1b. The R-squared value is 0.702 in Model 1, indicating the satisfactory explanatory power of the model.

Table 2. Estimation results of the effects of FDI on innovation efficiency.

\begin{tabular}{ccccc}
\hline \multirow{2}{*}{ Independent Variables } & \multicolumn{2}{c}{ CRE_EFCY (1) } & \multicolumn{2}{c}{ COM_EFCY (2) } \\
\cline { 2 - 5 } & Coefficient & S.E & Coefficient & S.E \\
\hline RED investment & 0.3381 & 0.233 & 0.4360 & 0.281 \\
Q_PERSONNEL & -0.0003 & 0.028 & -0.0195 & 0.028 \\
per-capita GDP & 0.0138 & 0.029 & -0.0251 & 0.026 \\
GOVERN_SUP & $-0.3114^{* * *}$ & 0.020 & $-0.0666^{* * *}$ & 0.024 \\
RED_INFRATRUCTURE & 0.0471 & 0.040 & 0.0602 & 0.045 \\
Q_UNIVERSITY & -0.0249 & 0.017 & & 0.0292 \\
AVE_FIRMSIZE & & & $0.0204^{* *}$ & 0.009 \\
FDI & $0.0577^{* * *}$ & 0.008 & 0.020 \\
CONSTANT & $-0.9962^{* * *}$ & 0.176 & $-0.4601 *$ & 0.266 \\
Number of obs & \multicolumn{2}{c}{210} & \multicolumn{2}{c}{210} \\
Hausman chi ${ }^{2}$ Test & $103.03, p<0.01$ & random effect \\
Model effects & \multicolumn{2}{c}{ fixed effect } & 0.05 \\
\hline
\end{tabular}

Note: Level of statistical significance: ${ }^{* * *} p \leq 0.01,{ }^{* *} p \leq 0.05,{ }^{*} p \leq 0.1$.

For the second set of hypotheses, the results of Model 3 show that $C_{-}$INS-UNI has a significant influence on CRE_EFCY $(\beta=0.0314, p<0.01)$, supporting H2a (Table 3). This finding indicates that $R \& D$ cooperation between universities and institutes tends to be more profound in the knowledge creation stage. For example, universities are able to use the advanced equipment of institutes to carry out scientific research, while universities can share their basic research achievements with institutes. Consequently, their cooperation can improve the efficiency and quality of knowledge innovation. GOVERN_SUP in the models has a negative effect on innovation efficiency. Indeed, the government formulates specific policies and provides R\&D funding to promote innovation activities. For example, government statistics show that $R \& D$ institutes and universities receive 10 times more funding from the government than from enterprises [58]. However, the excessive interference of government tends to see UIC deviate from market guidance, leading to a lack of effective incentives and negatively affecting innovation performance.

In relation to COM_EFCY in Model 4, only C_IND-INS exerts a significant effect on innovation efficiency $(\beta=0.0499, p<0.05)$, whereas the effect of $C_{-} I N S-U N I(\beta=-0.0221$, n.s.) is non-significant. The results of this model reveal that innovation efficiency in the technology commercialization stage is to some extent influenced by internal technology spillovers, where $C_{-} I N D$-INS has a stronger and more significant influence than C_INS-UNI. This finding might occur because, compared with the universities who are more engaged in basic research, the institute's emphasis is on applied research, 
where their research orientation and $R \& D$ capability are able to better meet the needs of the industries. Therefore, C_IND-INS facilitates COM_EFCY more effectively.

Table 3. Estimation results of the effects of UIC on innovation efficiency.

\begin{tabular}{|c|c|c|c|c|}
\hline \multirow{2}{*}{ Independent Variables } & \multicolumn{2}{|c|}{ CRE_EFCY (3) } & \multicolumn{2}{|c|}{ COM_EFCY (4) } \\
\hline & Coefficient & S.E & Coefficient & S.E \\
\hline RED investment & 0.4339 & 0.304 & 0.4244 & 0.297 \\
\hline Q_PERSONNEL & -0.0551 & 0.099 & -0.0110 & 0.029 \\
\hline per-capita GDP & 0.0566 & 0.055 & -0.0206 & 0.026 \\
\hline GOVERN_SUP & $-0.3293^{* * *}$ & 0.023 & $-0.0768^{* * *}$ & 0.024 \\
\hline RED_INFRATRUCTURE & 0.0788 & 0.055 & 0.0508 & 0.046 \\
\hline Q_UNIVERSITY & -0.0034 & 0.044 & & \\
\hline$\widetilde{A V E} F I I R M S I Z E$ & & & 0.0264 & 0.020 \\
\hline C_INS-UNI & $0.0314^{* * *}$ & 0.007 & & \\
\hline C_IND-INS & & & $0.0499 * *$ & 0.020 \\
\hline C-IND-UNI & & & -0.0221 & 0.017 \\
\hline CONSTANT & $-0.6401^{* * *}$ & 0.234 & $-0.4718^{*}$ & 0.279 \\
\hline Number of obs & \multicolumn{2}{|l|}{210} & \multicolumn{2}{|l|}{210} \\
\hline Hausman chi ${ }^{2}$ Test & \multirow{2}{*}{\multicolumn{2}{|c|}{$\begin{array}{c}81.09, p<0.01 \\
\text { fixed effect }\end{array}$}} & \multirow{2}{*}{\multicolumn{2}{|c|}{$4.09, p>0.05$}} \\
\hline Model effects & & & & \\
\hline
\end{tabular}

Level of statistical significance: ${ }^{* * *} p \leq 0.01,{ }^{* *} p \leq 0.05,{ }^{*} p \leq 0.1$.

Third, we added FDI and UIC into Nodels 5 and 6 to compare the effect of FDI with that of UIC on innovation efficiency (Table 4). In Model 5, the coefficients of FDI and C_INS-UNI are $0.0498(p<0.01)$ and $0.0085(p>0.1)$, respectively. The regression coefficient estimate for FDI in Model 5 implies that a one standard deviation ( $\mathrm{SD}=1.585)$ increase in FDI leads to a 0.0789 increase in the value of $C R E \_E F C Y$, while the coefficient estimate for C_INS-UNI is non-significant. Thus, FDI has a higher coefficient and stronger significance in Model 5 than C_INS-UNI, rejecting H3a. One possible reason is that, compared with developed countries, China's basic research is still lagging [3]. Most basic research takes place in the knowledge creation stage and relies more on frontier knowledge, high-tech technology, and advanced equipment obtained from abroad. As a result, external knowledge spillovers facilitate basic research in the knowledge creation stage, thereby promoting an improvement in innovation efficiency to a higher extent.

Table 4. Estimation results of comparing the effect of FDI with that of UIC on innovation efficiency.

\begin{tabular}{|c|c|c|c|c|}
\hline \multirow{2}{*}{ Independent Variables } & \multicolumn{2}{|c|}{ CRE_EFCY (5) } & \multicolumn{2}{|c|}{ COM_EFCY (6) } \\
\hline & Coefficient & S.E & Coefficient & S.E \\
\hline RED investment & 0.3948 & 0.287 & 0.3731 & 0.300 \\
\hline Q_PERSONNEL & 0.0002 & 0.094 & -0.0124 & 0.028 \\
\hline per-capita GDP & 0.0420 & 0.052 & -0.0186 & 0.026 \\
\hline GOVERN_SUP & $-0.3086^{* * *}$ & 0.022 & $-0.0677^{*}$ & 0.025 \\
\hline RED_INFRATRUCTURE & 0.0420 & 0.053 & 0.0513 & 0.046 \\
\hline Q_UNIVERSITY & -0.0031 & 0.041 & & \\
\hline AVE_FIRMSIZE & & & 0.0271 & 0.020 \\
\hline C_INS-UNI & 0.0085 & 0.008 & & \\
\hline C_IND-INS & & & $0.0393 *$ & 0.022 \\
\hline C-IND-UNI & & & -0.0227 & 0.017 \\
\hline FDI & $0.0498^{* * *}$ & 0.010 & 0.0132 & 0.011 \\
\hline CONSTANT & $-0.9959^{* * *}$ & 0.232 & $-0.5168 *$ & 0.281 \\
\hline Number of obs & \multicolumn{2}{|c|}{210} & \multicolumn{2}{|c|}{210} \\
\hline Hausman chi ${ }^{2}$ Test & \multirow{2}{*}{\multicolumn{2}{|c|}{$\begin{array}{c}282.06, p<0.01 \\
\text { fixed effect }\end{array}$}} & \multirow{2}{*}{\multicolumn{2}{|c|}{$\begin{array}{l}5.10, p>0.05 \\
\text { random effect }\end{array}$}} \\
\hline Model effects & & & & \\
\hline
\end{tabular}

Note: Level of statistical significance: ${ }^{* * *} p \leq 0.01,{ }^{* *} p \leq 0.05,{ }^{*} p \leq 0.1$. 
According to Model 6, C_IND-INS exerts a significant effect on COM_EFCY, whereas the effect of FDI is not significant, supporting H3b. The regression coefficient of FDI is $0.0393(p<0.1)$; hence, a one standard deviation $(S D=1.119)$ increase in FDI means that COM_EFCY increases by 0.0440 . The reason for this phenomenon may depend on the following aspects. Regarding the protection of core technology, foreign enterprises, to maintain their monopoly positions and competitive advantage relative to domestic enterprises, would not transfer genuine technology to the host country in case domestic enterprises absorb and commercialize these technologies. Therefore, to improve COM_EFCY, China could only foster genuine technological innovation through the internal technology spillovers generated by UIC.

\section{Conclusions}

This study divided the innovation process into two sequential stages, namely knowledge creation and technology commercialization, and then employed a network DEA approach to measure innovation efficiency in each stage. Panel econometric models were applied to compare the influence of FDI with that of UIC on innovation efficiency in each stage, based on a dataset of 30 provinces in China from 2009 to 2015. The presented analysis allowed us to draw three main findings.

First, average innovation efficiency across all provinces was still fairly low, but it showed a gradual upward trend from 2009 to 2015. When we analyze the decomposition of innovation efficiency in each stage, knowledge creation efficiency (CRE_EFCY) shows a higher average score and more efficient processes than technology commercialization efficiency (COM_EFCY). The spatial pattern for the 30 provinces shows that provinces with higher values of COM_EFCY are located in northwestern China, which indicates the spatial heterogeneity of innovation efficiency.

Second, external technology spillovers, as represented by FDI, have a significant influence on CRE_EFCY and COM_EFCY. In Model 3, we find that UIC, specifically institute-university cooperation (C_INS-UNI), has a significant influence on innovation efficiency in the knowledge creation stage. However, only industry-institute cooperation (C_IND-INS) shows a significant and positive impact on COM_EFCY.

Finally, in comparison with UIC, FDI has a greater positive influence on innovation efficiency in the knowledge creation stage, while between the two examined types of cooperation, only industry-institute linkages exhibit a stronger association with innovation efficiency in the technology commercialization stage.

Based on these results, several implications and strategies can be discussed. First, both internal and external technology spillovers in China have a positive impact on innovation efficiency and the mechanism of their impact is a complex process. The goal of China's regional innovation strategy should thus be to combine internal and external technology spillovers, not only introducing foreign technology through FDI, but also using internal UIC to nurture indigenous innovation.

Second, in the process of UIC, industry should gradually become the main funder of R\&D investment and technological innovation, strengthening its connectivity with universities and institutes by funding R\&D activities and fostering R\&D talent. This approach could maximize the positive effects of internal technology spillovers, laying the foundation for the absorption of external knowledge and offering endogenous impetus for regional innovation.

Third, in terms of FDI, the choice of introducing external technology should be based on whether it will enhance indigenous innovation. Further, it is necessary to encourage foreign enterprises to set up R\&D institutions in China to allow them to forge innovative cooperation with universities, institutes, and domestic enterprises.

The study has several limitations to overcome in further research. As innovation is a complex process, it is biased only to employ manpower and $R \& D$ expenditure as the input indicators to measure the innovation efficiency. In addition, the intangible (hardly quantifiable) outputs during two-stage innovation process also trouble the accurate measurement of inputs' contributions. One kind of potential study in this context is to incorporate important innovative elements into the present network 
DEA model from the systems perspective. The second limitation, which is common for the comparative studies of cross-region innovation performance, is that the obtained observations (that is, provinces in this study) cannot be completely independent in terms of the innovative input-output correspondence. It must be recognized that there would be spatial spillover effect or spatial correlation in innovative activities among 30 provinces. The third limitation is attributable to the deterministic property of the network DEA model. As indicated by the diagnostic analysis for the influences of outliers and statistical noise on innovation efficiency estimations, efficiency estimates in the context of deterministic DEA models may be biased. As such, it is necessary to construct the empirical distribution of the scores by means of bootstrapping methods [71] for the current network DEA model in the future study.

Acknowledgments: This research has been funded by the National Natural Science Foundation of China (No. 41471108).

Author Contributions: Debin Du and Xionghe Qin conceived and designed the paper; Xionghe Qin analyzed the data; Xionghe Qin wrote the paper.

Conflicts of Interest: The authors declare no conflict of interest.

\section{References}

1. Wunsch-Vincent, S.; Lanvin, B.; Dutta, S. The Global Innovation Index 2015: Effective Innovation Policies for Development. Available online: https://ideas.repec.org/p/ess/wpaper/id7491.html (accessed on 4 September 2017).

2. Yun, J.J. How do we conquer the growth limits of capitalism? Schumpeterian Dynamics of Open Innovation. J. Open Innov. Technol. Mark. Complex. 2015, 1, 17. [CrossRef]

3. Qiu, J. China goes back to basics on research funding: Core science gets budget boost in a bid to change research culture and increase innovation. Nature 2014, 507, 148-150. [CrossRef] [PubMed]

4. He, B.; Fan, S. The evolution and impact factors of university technology transfer efficiency in China: Based on the method of Bootstrap-DEA and panel Tobit model. Sci. Sci. Manag. S T 2013, 34, 85-94.

5. Angang, H. Embracing China's New Normal. Foreign Aff. 2015, $94,8$.

6. Etzkowitz, H.; Webster, A.; Gebhardt, C.; Terra, B.R.C. The future of the university and the University of the Future: Evolution of ivory tower to entrepreneurial paradigm. Res. Policy 2000, 29, 313-330. [CrossRef]

7. Motohashi, K. University-industry collaborations in Japan: The role of new technology-based firms in transforming the National Innovation System. Res. Policy 2005, 34, 583-594. [CrossRef]

8. Gibbons, M.; Limoges, C.; Nowotny, H.; Schwartzman, S.; Scott, P.; Trow, M. The New Production of Knowledge: The Dynamics of Science and Research in Contemporary Societies; Sage: Newcastle upon Tyne, UK, 1994.

9. Maietta, O.W. Determinants of university-firm R\&D collaboration and its impact on innovation: A perspective from a low-tech industry. Res. Policy 2015, 44, 1341-1359.

10. Dosi, G.; Freeman, C.; Nelson, R.; Silverberg, G.; Soete, L. Technical Change and Economic Theory; Pinter: London, UK, 1988; Volume 988.

11. Yun, J.J.; Won, D.; Park, K. Dynamics from open innovation to evolutionary change. J. Open Innov. Technol. Mark. Complex. 2016, 2, 7. [CrossRef]

12. Lundvall, B.-A. Innovation as an interactive process: User-producer interaction to the national system of innovation. Afr. J. Sci. Technol. Innov. Dev. 2009, 1, 10-34.

13. García-Valderrama, T.; Mulero-Mendigorri, E. Content validation of a measure of R\&D effectiveness. RED Manag. 2005, 35, 311-331.

14. Hansen, M.T.; Birkinshaw, J. The innovation value chain. Harv. Bus. Rev. 2007, 85, 121. [PubMed]

15. Yu, Y.; Liu, D. The Effect of the Space Outflow of China's Regional Innovation and the Effect of the Outflow of Value Chanins: A Study, from the Perspective of the Innovative Value Chain, on the Model of the Panel of Multidimentsional Space. Manag. World 2013, 7, 6-20.

16. Carayannis, E.G.; Grigoroudis, E.; Goletsis, Y. A multilevel and multistage efficiency evaluation of innovation systems: A multiobjective DEA approach. Expert Syst. Appl. 2016, 62, 63-80. [CrossRef]

17. Vahter, P. Does FDI spur productivity, knowledge sourcing and innovation by incumbent firms? Evidence from manufacturing industry in Estonia. World Econ. 2011, 34, 1308-1326. [CrossRef] 
18. $\mathrm{Fu}, \mathrm{X}$. Foreign direct investment and managerial knowledge spillovers through the diffusion of management practices. J. Manag. Stud. 2012, 49, 970-999. [CrossRef]

19. Li, J.; Chen, D.; Shapiro, D.M. FDI Spillovers at the National and Subnational Level: The Impact on Product Innovation by Chinese Firms. Manag. Organ. Rev. 2013, 9, 413-435. [CrossRef]

20. Girma, S.; Gong, Y.; Görg, H. Foreign direct investment, access to finance, and innovation activity in Chinese enterprises. World Bank Econ. Rev. 2008, 22, 367-382. [CrossRef]

21. Hou, J.; Chen, H.; Xu, J. External Knowledge Sourcing and Green Innovation Growth with Environmental and Energy Regulations: Evidence from Manufacturing in China. Sustainability 2017, 9, 342. [CrossRef]

22. Elmawazini, K.; Nwankwo, S. Foreign direct investment: Technology gap effects on international business capabilities of sub-Saharan Africa. Thunderbird Int. Bus. Rev. 2012, 54, 457-467. [CrossRef]

23. Pan, W. The Spill-over Effects of FDI on China's Industrial Sectors: A Panel Data Analysis. World Econ. 2003, 26, 3-7.

24. Meyer, K.E.; Sinani, E. When and where does foreign direct investment generate positive spillovers? A meta-analysis. J. Int. Bus. Stud. 2009, 40, 1075-1094. [CrossRef]

25. Hagedoorn, J.; Duysters, G. External sources of innovative capabilities: The preferences for strategic alliances or mergers and acquisitions. J. Manag. Stud. 2002, 39, 167-188. [CrossRef]

26. Garcia-Perez-de-Lema, D.; Madrid-Guijarro, A.; Martin, D. P. Influence of university-firm governance on SMEs innovation and performance levels. Technol. Forecast. Soc. Chang. 2016, in press. Available online: http:/ / dx.doi.org/10.1016/j.techfore.2016.04.003 (accessed on 10 August 2017).

27. George, G.; Zahra, S.A.; Wood, D.R. The effects of business-university alliances on innovative output and financial performance: A study of publicly traded biotechnology companies. J. Bus. Ventur. 2002, 17, 577-609. [CrossRef]

28. Huang, M.-H.; Chen, D.-Z. How can academic innovation performance in university-industry collaboration be improved? Technol. Forecast. Soc. Chang. 2016, in press. Available online: http:/ /dx.doi.org/10.1016/j. techfore.2016.03.024 (accessed on 10 August 2017).

29. Guan, J.C.; Yam, R.C.; Mok, C.K. Collaboration between industry and research institutes/universities on industrial innovation in Beijing, China. Technol. Anal. Strateg. Manag. 2005, 17, 339-353. [CrossRef]

30. Gemünden, H.G.; Heydebreck, P.; Herden, R. Technological interweavement: A means of achieving innovation success. RD Manag. 1992, 22, 359-376. [CrossRef]

31. Griliches, Z. Patent Statistics as Economic Indicators: A Survey; National Bureau of Economic Research: Cambridge, MA, USA, 1990.

32. Wei, W.X.; Chen, D.; Hu, D. Study on the Evolvement of Technology Development and Energy Efficiency-A Case Study of the Past 30 Years of Development in Shanghai. Sustainability 2016, 8, 457. [CrossRef]

33. Kinoshita, Y. Technology Spillovers through Foreign Direct Investment. Available online: https://www. cerge-ei.cz/pdf/wp/Wp139.pdf (accessed on 4 September 2017).

34. Cassiman, B.; Veugelers, R. In search of complementarity in innovation strategy: Internal R\&D and external knowledge acquisition. Manag. Sci. 2006, 52, 68-82.

35. Hershberg, E.; Nabeshima, K.; Yusuf, S. Opening the Ivory Tower to Business: University-Industry Linkages and the Development of Knowledge-Intensive Clusters in Asian Cities; Elsevier: Amsterdam, the Netherlands, 2007.

36. Howells, J.; Nedeva, M.; Georghiou, L. Industry-Academic Links in the UK; Higher Education Funding Council for England Bristol: Stuart Kewitt, UK, 1998.

37. Schartinger, D.; Rammer, C.; Fischer, M.M.; Fröhlich, J. Knowledge interactions between universities and industry in Austria: Sectoral patterns and determinants. Res. Policy 2002, 31, 303-328. [CrossRef]

38. Perkmann, M.; Tartari, V.; McKelvey, M.; Autio, E.; Broström, A.; D’Este, P.; Fini, R.; Geuna, A.; Grimaldi, R.; Hughes, A. Academic engagement and commercialisation: A review of the literature on university-industry relations. Res. Policy 2013, 42, 423-442. [CrossRef]

39. Feller, I.; Ailes, C.P.; Roessner, J.D. Impacts of research universities on technological innovation in industry: Evidence from engineering research centers. Res. Policy 2002, 31, 457-474. [CrossRef]

40. Romijn, H.; Albaladejo, M. Determinants of innovation capability in small electronics and software firms in southeast England. Res. Policy 2002, 31, 1053-1067. [CrossRef]

41. Tidd, J.; Bessant, J.; Pavitt, K.; Wiley, J. Managing Innovation: Integrating Technological, Market and Organizational Change; Wiley: Chichester, UK, 1998.

42. Forrester, J.W. Industrial dynamics. J. Oper. Res. Soc. 1997, 48, 1037-1041. [CrossRef] 
43. Charnes, A.; Cooper, W.W.; Rhodes, E. Measuring the efficiency of decision making units. Eur. J. Oper. Res. 1978, 2, 429-444. [CrossRef]

44. Färe, R. Measuring Farrell efficiency for a firm with intermediate inputs. Acad. Econ. Pap. 1991, 19, 329-340.

45. Färe, R.; Grosskopf, S.; Whittaker, G. Network dea. In Modeling Data Irregularities and Structural Complexities in Data Envelopment Analysis; Springer: Berlin, Germany, 2007; pp. 209-240.

46. Lewis, H.F.; Sexton, T.R. Network DEA: Efficiency analysis of organizations with complex internal structure. Comput. Oper. Res. 2004, 31, 1365-1410. [CrossRef]

47. Prieto, A.M.; Zofío, J.L. Network DEA efficiency in input-output models: With an application to OECD countries. Eur. J. Oper. Res. 2007, 178, 292-304. [CrossRef]

48. Tone, K.; Tsutsui, M. Network DEA: A slacks-based measure approach. Eur. J. Oper. Res. 2009, 197, $243-252$. [CrossRef]

49. Yu, M.-M. Assessment of airport performance using the SBM-NDEA model. Omega 2010, 38, 440-452. [CrossRef]

50. Jaffe, A.B.; Trajtenberg, M.; Henderson, R. Geographic localization of knowledge spillovers as evidenced by patent citations. Q. J. Econ. 1993, 108, 577-598. [CrossRef]

51. Aghion, P.; Blundell, R.; Griffith, R.; Howitt, P.; Prantl, S. The effects of entry on incumbent innovation and productivity. Rev. Econ. Stat. 2009, 91, 20-32. [CrossRef]

52. Wang, B.; Zhang, M. Marketization, collaboration with academics and innovation performance of enterprises. Stud. Sci. Sci. 2015, 5, 748-757.

53. Luo, J. R\&D Input Threshold, FDI and Innovation Capability in China: An Analysis Based on Threshold Effect. J. Int. Trade 2014, 8, 135-146.

54. Cohen, W.M.; Levinthal, D.A. Absorptive capacity: A new perspective on learning and innovation. Admin. Sci. Q. 1990, 35, 128-152. [CrossRef]

55. Wang, E.C.; Huang, W. Relative efficiency of R\&D activities: A cross-country study accounting for environmental factors in the DEA approach. Res. Policy 2007, 36, 260-273.

56. Klenow, P.J.; Rodriguez-Clare, A. The neoclassical revival in growth economics: Has it gone too far? NBER Macroecon. Annu. 1997, 12, 73-103. [CrossRef]

57. Fan, H. A Hypothesis on Effective Demand Size, R\& D Expenditure and National Innovation Capacity. Econ. Res. J. 2007, 3, 34-45.

58. Department of S\&T of National Bureau of Statistics. Statistical Yearbook of China Science and Technology; China Statistics Press: Beijing, China, 2016.

59. National Bureau of Statistics. China Statistical Yearbook; China Statistics Press: Beijing, China, 2016.

60. Xie, H.; Zou, J.; Jiang, H.; Zhang, N.; Choi, Y. Spatiotemporal pattern and driving forces of arable land-use intensity in China: Toward sustainable land management using emergy analysis. Sustainability 2014, 6, 3504-3520. [CrossRef]

61. Peng, H.; Tan, X.; Li, Y.; Hu, L. Economic Growth, Foreign Direct Investment and $\mathrm{CO}_{2}$ Emissions in China: A Panel Granger Causality Analysis. Sustainability 2016, 8, 233. [CrossRef]

62. De Smith, M.J.; Goodchild, M.F.; Longley, P. Geospatial Analysis: A Comprehensive Guide to Principles, Techniques and Software Tools; Troubador Publishing Ltd.: Leicester, UK, 2007.

63. Bai, X.-J.; Yan, W.-K.; Chiu, Y.-H. Performance evaluation of China's Hi-tech zones in the post financial crisis era-Analysis based on the dynamic network SBM model. China Econ. Rev. 2015, 34, 122-134. [CrossRef]

64. Kokko, A. Technology, market characteristics, and spillovers. J. Dev. Econ. 1994, 43, 279-293. [CrossRef]

65. Fleisher, B.; Li, H.; Zhao, M.Q. Human capital, economic growth, and regional inequality in China. J. Dev. Econ. 2010, 92, 215-231. [CrossRef]

66. Burnham, K.P.; Anderson, D.R. Model Selection and Multimodel Inference: A Practical Information-Theoretic Approach; Springer Science \& Business Media: Berlin, Germany, 2003.

67. Hu, M.-C.; Mathews, J.A. National innovative capacity in East Asia. Res. Policy 2005, 34, 1322-1349. [CrossRef]

68. Li, X. Sources of external technology, absorptive capacity, and innovation capability in Chinese state-owned high-tech enterprises. World Dev. 2011, 39, 1240-1248. [CrossRef]

69. Hong, J.; Feng, B.; Wu, Y.; Wang, L. Do government grants promote innovation efficiency in China's high-tech industries? Technovation 2016, 57, 4-13. [CrossRef] 
70. Hausman, J.A. Specification tests in econometrics. Econ. J. Econ. Soc. 1978, 46, 1251-1271. [CrossRef]

71. Simar, L.; Wilson, P.W. Sensitivity analysis of efficiency scores: How to bootstrap in nonparametric frontier models. Manag. Sci. 1998, 44, 49-61. [CrossRef]

(c)

(C) 2017 by the authors. Licensee MDPI, Basel, Switzerland. This article is an open access article distributed under the terms and conditions of the Creative Commons Attribution (CC BY) license (http://creativecommons.org/licenses/by/4.0/). 